\title{
Soil quality and microbial population of the Rivers State University Arboretum, Port Harcourt, Nigeria
}

\author{
Chukunda, F. A. ${ }^{1 \star}$, Baraka, R. E. ${ }^{2}$ and Alika, V. C. ${ }^{1}$ \\ ${ }^{1}$ Department of Forestry and Environment, Faculty of Agriculture, Rivers State University of Science and Technology, \\ Port Harcourt, Nigeria. \\ ${ }^{2}$ Department of Crop and Soil Science, Niger Delta University, Wilberforce Island, Bayelsa State, Nigeria.
}

Accepted 10 December, 2019

\begin{abstract}
This research evaluated soil quality and microbial population of Rivers State University Arboretum, Port Harcourt, Nigeria. The experiment was carried out in a completely randomized design (CRD) using systematic random sampling. A composite soil sample of 0 to $15 \mathrm{~cm}$ depth was collected using soil auger, showed that the soil physic-chemical properties were significant $(P \leq 0.05)$ differences between each three subplots in the soil pH of the soil samples collected. Plot I $(6.8 \pm 0.08)>$ Plot II $(6.0 \pm 0.02)>$ Plot III $(6.5 \pm$ 0.05). Soil electrical conductivity of the subplots of the arboretum significantly differed from each plots, $\mathrm{P}$ I $(58.50 \pm 0.04 \mu \mathrm{s} / \mathrm{cm}), \mathrm{P}$ II $(47.30 \pm 0.06 \mu \mathrm{s} / \mathrm{cm})$ and $\mathrm{P}$ III $(45.30 \pm 0.06 \mu \mathrm{s} / \mathrm{cm})$. Total organic carbon (TOC) results showed significant $(P \leq 0.05)$ differences in the subplots; $P$ III $(1.62 \pm 0.05 \%)$ followed by $P$ II $(1.35 \pm$ $0.05 \%)$ and the least was $\mathrm{PI}(0.09 \pm 0.03 \%)$. Total available phosphorus present in the three subplots also differed significantly $(P \leq 0.05)$, $P$ II had the highest total available phosphorus $(0.013 \pm 0.02 \mathrm{mg} / \mathrm{kg})$ followed by P I $(0.009 \pm 0.01 \mathrm{mg} / \mathrm{kg})$ and P III $(0.008 \pm 0.02 \mathrm{mg} / \mathrm{kg})$ was the least, whereas the total nitrogen showed no significant $(P \geq 0.05)$ differences among the three subplots, $P$ III $(0.12 \pm 0.06 \mathrm{mg} / \mathrm{kg}), P$ II $(0.12 \pm 0.06$ $\mathrm{mg} / \mathrm{kg})$ and $\mathrm{P}$ । $(0.10 \pm 0.04 \mathrm{mg} / \mathrm{kg})$ was the least. Generally, the results of the soil physio-chemical properties have showed that subplot I was less fertile compared to the two other subplots II and III. P I; Alcaligenes sp., Micrococcus sp., Acinetobacter sp., P II had the following bacterial; Pseudomonas sp., Acinetobacer sp. and Alcaligenes sp. and P III had Bacillus sp., Aeromonas sp. However, the fungal population also differed significantly from each subplots, $\mathrm{P}$ I; Aspergillus flavus, Microsporum canis, Aspergillus terreus, Penicillium sp., Fusarium sp., and Acremonium sp. In P II; Malironchea sp, Aspergillus terreus, Trichophyton terrestie, Gliocladium sp., Aspergillus nidulans and Phaeoacremonium parasiticum. P III; Malbranchea sp., Aspergillus nidulans, Trichophyton tonsurans, Fusarium sp. and Penicullium sp.
\end{abstract}

Keywords: Soil quality, microbial population, Arboretum, total heterotrophic bacterial count, total fungi count.

${ }^{*}$ Corresponding author. E-mail: onyifrank2002@yahoo.com. Tel: 08037501179.

\section{INTRODUCTION}

Soil is generally regarded as the layer of unconsolidated particles derived from weathered rock, organic material (humus), water and air that form the upper surface over much of the earth and support plant growth. The formation of soil depends on the parent materials that is, the original material from which the soil is derived, the climate and topography of the area, the organisms present in the soil, and the time over which the soil has been formed. Soils are often classified in terms of their structure and texture (Monger et al., 2006).

The proportions of the soil components vary with the different types of soils, but a typical "good" forest soil is about $45 \%$ minerals, $25 \%$ air, $25 \%$ water and $5 \%$ organic matter. This combination provides good drainage, aeration, and organic matter (Enger and Smith, 2008).

Soil organic matter (SOM) is the organic matter 
component of soil, consisting of plant and animal residues at various stages of decomposition, cells and tissues of soil organisms, and substances synthesized by soil organisms.

Brady and Weil (2007) affirm that soil organic matter exerts numerous positive effects on soil physical and chemical properties, as well as the soil capacity to provide regulatory eco system services. Beare et al. (1994) reported that the presence of soil organic matter is regarded as being critical for soil function and quality.

Organic matter has been described by soil scientists as the organic component of soil which includes the residue of dead plants, animals and organisms. It consists of nutrients necessary for plant growth such as nitrogen, phosphorous and potassium (Monger et al., 2006).

Soil organic matter is important because it improves both the physical and chemical properties of soil and has several beneficial effects on forest soil quality. Soil organic matter helps soil particles, thus decreasing erosion. It also improves soil structure and workability enhances aeration and water penetration, increases water-holding capacity, and stores and supplies nutrients for growth of both plants and soil micro-organisms (Ademir et al., 2009).

Organic agriculture is gaining worldwide acceptance and has been expanding at annual rate of $20 \%$ in the last decade accounting for over 24 million hectares worldwide (Waser and Yussefi, 2004).

This system avoids applications of synthetic fertilizers and pesticides, and use of organic inputs and recycling for nutrient supply and emphasizes cropping system design and biological processes for pests' management (Araujo et al., 2008). Also, it can reduce some negative effects attributed to conventional agriculture and has potential benefits in enhancing soil quality (Brendecke et al., 1993).

Soil quality is the capacity of soil to maintain some key ecological functions, such as decomposition and formation of soil organic matter (Doran et al., 1996). Microbial processes are important for the management of farming system and improvement of soil quality. Microbial respiration of soil has received considerable attention because it can be used as a soil quality indicator (Brendecke et al., 1993) and it is an important variable to quantify soil microbial activity.

Soil microbial biomass and carbon is considered the most dynamic and labile component of soil organic carbon. Thus, the pool of soil microbial carbon, its activity and composition are key parameters in soil processes (Brendecke et al., 1993). The number of studies comparing organic and conventional systems is limited, mainly on soil microbial processes.

This research is aimed at determining physico-chemical properties of the sampled soil of forest Abrboretum of Rivers State, Nkpolu Oroworukwo isolate and identify fungal and bacteria present in the sampled soil and access the total heterotrophic bacterial count (THBC) and total fungi count (TFC) in the sampled soil.

\section{MATERIALS AND METHODS}

\section{Study area}

The study was conducted in the Arboretum of Forestry and Environment, Rivers State University, Nkpolu-Oroworukwo situated in Latitude $4.51^{\circ} \mathrm{N}$ and Longitude $7.01^{\circ} \mathrm{E}$ at an Altitude of 223 above sea level (Tariah et al., 1991).

\section{Methods of sampling and sample collection}

In this study systematic sampling design was employed for laying of plots in the arboretum. A transect was laid measuring $10 \mathrm{~m} \times 100 \mathrm{~m}$ mark and later divided into three equal sub-plots of $10 \mathrm{~m} \times 33 \mathrm{~m}$ for easy of soil collection. The soil samples were collected in a completely randomized design (CRD) due to the homogeneity of the arboretum soils. Then a soil sample of 0 to $15 \mathrm{~cm}$ depth was obtained using soil auger (Obire and Wemedo, 1996).

The soil samples were collected into sterile McCartney bottles. All the sample bottles were preserved in an ice-cooled container and transported to the laboratory for physico-chemical and microbiological analysis. All microbiological analysis was carried out under asceptic conditions.

\section{Soil pH}

This was determined in a $2.5(\mathrm{~W} / \mathrm{V})$ soil water suspension (Hanes, 1984). $10 \mathrm{~g}$ of the soil samples were weighed using electrical weighing balance and put into a beaker $20 \mathrm{ml}$ of distilled water was added to the various samples using $\mathrm{pH}$ meter, Model 2211 according to the method of Mclean (1982) and the mean value obtained after two replications.

\section{Total organic carbon (TOC)}

This was determined by the Walkley and Black oxidation method as modified by Nelson and Sommers (1982), while organic matter content was calculated by multiplying the percentage organic carbon by 1.72 . The percentage total organic carbon was calculated using the formula:

$\%$ Total organic carbon $=\frac{\mathrm{N}(\mathrm{T}-\mathrm{B}) \times 0.390}{\mathrm{~W}}$

Where: $\mathrm{N}=$ Normality of acid, $\mathrm{T}=$ Titre $(\mathrm{ml})$ for sample, $\mathrm{B}=$ Blank reading $(\mathrm{ml}), \mathrm{W}=$ weight of soil used.

\section{Total nitrogen}

Total nitrogen was determined using the regular semi-micro Kjeldahl method (Bremner and Mulvaney, 1982). In this method, a representative air-dried soil was ground to pass through $0.5 \mathrm{~mm}$ sieve. A gram of the air-dried soil was weighed into tecator tubes and then mixed with catalyst $\left(\mathrm{Se}, \mathrm{CuSO}_{4}+\mathrm{Na}_{2} \mathrm{SO}_{4}\right)+$ Concentrated $\mathrm{H}_{2} \mathrm{SO}_{4}$. This was digested on a tecator block until the digest cleared. The digest was distilled and titrated with $0.01 \mathrm{~N}$ standard sulphuric acid (Buondonno et al., 1993). The percent total nitrogen was then determined using the formular:

$\%$ Total nitrogen $=\frac{\mathrm{N}(\mathrm{T}-\mathrm{B}) \times 1.4}{\mathrm{~W}}$

Where: $\mathrm{N}=$ Normality of acid, $\mathrm{T}=$ Titre $(\mathrm{ml})$ sample, $\mathrm{B}=$ Blank reading $(\mathrm{ml}), \mathrm{W}=$ Weight of soil used. 


\section{Available phosphorus}

The available phosphorus was extracted by the Bray-1 procedure and analyzed using the molybdate Electrical conductivity procedure described by Murphy and Riley (1962) and Watanabe and Olsen (1965).

\section{Data analysis}

The experiment data collected was analyzed by analysis of variance (ANOVA) using SPSS Genstat software as described by Steel and Torrie (1980).

\section{Isolation and enumeration of microbial population}

Isolation and enumeration of total heterotrophic bacterial count and total fungi count from the soil samples through serial dilution. Serial dilutions of samples were done three times. Aliquots $(0.1 \mathrm{ml})$ of appropriate dilution was spread, plated using a sterile bent glass rods into the surfaces of fresh sterile dried nutrient agar plates for bacteria and potato dextrose agar plates for fungi (Harrigan and MacCane, 1990; Obire and Wemedo, 1996; Ofunne, 1999). The inoculated plates were incubated at $37^{\circ} \mathrm{C}$ for $24 \mathrm{~h}$ for bacteria and 2 to 3 days for fungi. After incubation, plates that had significant growth was counted and the populations of bacteria was recorded in colony forming units per gram (cfu/g) while population of fungi was recorded in spore forming units per gram (cfu/g) soil.

Bacterial colonies were purified by sub-culturing into fresh sterile nutrient agar plates which was incubated at $37^{\circ} \mathrm{C}$ for $24 \mathrm{~h}$ and used as pure cultures for characterization of the isolates. Similarly, discrete colonies of fungi was sub cultured into PDA plates and incubated at $28^{\circ} \mathrm{C}$ for 3 to 5 days and the pure cultures used for characterization of fungal isolates (Ofunne, 1999; Chukunda and Offor, 2015).

Identification and characterization of bacterial and fungal isolates

Pure cultures of bacteria was obtained and subjected to various characterization procedures. The standard characterization tests performed include; gram stain, motility test, catalase, methyl red and Vogues Proskaver test. Others are urease, indole, protease, nitrate reduction, starch hydrolysis and sugar fermentation tests. The isolates were identified on the basis of their cultural, morphological and biochemical reactions (Cowan, 1974; Buchanan and Gibbons, 1994; Domsch et al., 1980).

Fungal isolates was characterized by macroscopic by observation colony morphology, colour of colony, texture, shape, surface appearance, and colour on the reverse plates (Abbey, 1995) and the wet preparation and slide culture methods by observing cultural characteristics to reveal the asexual and sexual reproductive structures like sporangia, conidial head, vegetative mycelia, septate and non-septate hyphae (Alexopoulos et al., 1962; Barnett and Hunter, 1972).

\section{RESULTS AND DISCUSSION}

\section{Physico-chemical properties of soil collected from the University Arboretum}

Soil type is sandy loam in the three subplots sampled. The soil of the three subplots are slightly acidic Plot II
(6.0 \pm 0.02$)$, Plot III $(6.5 \pm 0.05)$ though Plot I $(6.8 \pm 0.08)$ tending to neutrality. The soil electrical conductivity differed significantly $(P \leq 0.05)$ from each subplot, Plot I $(58.50 \pm 0.04 \mu \mathrm{s} / \mathrm{cm})$, Plot II $(47.30 \pm 0.06 \mu \mathrm{s} / \mathrm{cm})$ and Plot III $(45.30 \pm 0.06 \mu \mathrm{s} / \mathrm{cm})$. The total organic carbon (TOC) was found to be more in Plot III $(1.62 \pm 0.05 \%)$ followed by Plot II $(1.35 \pm 0.02 \%)$ and the least was Plot I $(0.09 \pm 0.03 \%)$ reason is due to litter fall was more in Plot III and II. Total amount of nitrogen and phosphorus in the three subplots are low and subplot I has a poor soil physico-chemical properties.

Soil $\mathrm{pH}$ is the most important chemical characteristics of the soil solution. The very strongly acid reaction values suggest possible low availability of both the macro and micro plant nutrients for uptake by plants. The soil $\mathrm{pH}$ (Plot I) acidic level may be attributed to leaching of bases, constant farming practices. In the study area, the soil $\mathrm{pH}$ is slightly acidic tending to neutral which likely encourage farming activities (Table 1). Chukunda et al., (2019) reported that vegetation type influences forest floor nutrient availability. This is probably due to differences in litter fall chemistry. This is in line with present research findings. The result on the soil $\mathrm{pH}$ values among the treatment plots showed that the three subplots significantly differ in their soil $\mathrm{pH}$. This was supported by the findings of Lindo and Visser (2003) since the present forest under investigation is mixed vegetation which may likely have different litter fall consequently affected the soil pH status of the forest.

The increase in total organic carbon (TOC) contents is important in tropical soil due to low levels of organic matter observed in soils. The high TOC is important since organic matter influenced soil physical, chemical and biological properties. These results are in accordance with Glover et al. (2000) and Melero et al. (2005) who observed that organic farming system promoted microbial processes. (Brendecke et al. 1993) The low level of TOC observed in the soil can be a cause of poor soil structure and low supply of plant nutrients (Nandi and Luffman, 2012; Anderson and Domsch, 1980).

Total Soil Organic carbon has significant impact chemical properties such as soil $\mathrm{pH}$ and electrical conductivity. Shawna et al. (2010) reported that organic carbon increases the $\mathrm{pH}$ and electrical conductivity values. Electrical conductivity is a measure of energy flow in the soil ecosystem, it indirectly measure activity and nutrient supply to plants. The present result obtained is coherence with the statement that electrical conductivity value for deciduous forest is slightly higher than coniferous forest. However, the forest stand of Rivers State University is a mixed plantation and had a higher value on electrical conductivity.

The low level of total nitrogen observed are characteristics of tropical soil where the high rate of mineralization does not allow high accumulation of carbon (Gachene and Kimaru, 2003). Total nitrogen is less than $0.02 \%$ and TOC values below $0.6 \%$ are 
Table 1. Physico-chemical properties of the forest soil, Rivers State University, Port Harcourt, Nigeria.

\begin{tabular}{llccccc}
\hline $\begin{array}{l}\text { Plot/soil } \\
\text { sample }\end{array}$ & Soil type & pH & $\begin{array}{c}\text { Electrical conductivity } \\
(\boldsymbol{\mu s} / \mathbf{c m})\end{array}$ & $\begin{array}{c}\text { Phosphorus } \\
(\mathbf{m g} / \mathbf{k g})\end{array}$ & $\begin{array}{c}\text { Total organic carbon } \\
(\mathrm{TOC}) \%\end{array}$ & $\begin{array}{c}\text { Nitrogen } \\
(\mathbf{m g} / \mathbf{k g})\end{array}$ \\
\hline I. & Sandy Loam & $6.8 \pm 0.08^{\mathrm{a}}$ & $58.50 \pm 0.04^{\mathrm{a}}$ & $0.009 \pm 0.01^{\mathrm{b}}$ & $0.09 \pm 0.03^{\mathrm{c}}$ & $0.10 \pm 0.04^{\mathrm{b}}$ \\
II. & Sandy Loam & $6.0 \pm 0.02^{\mathrm{a}}$ & $47.30 \pm 0.06^{\mathrm{b}}$ & $0.013 \pm 0.02^{\mathrm{a}}$ & $1.35 \pm 0.02^{\mathrm{b}}$ & $0.12 \pm 0.03^{\mathrm{a}}$ \\
III. & Sandy Loam & $6.5 \pm 0.05^{\mathrm{a}}$ & $45.30 \pm 0.06^{\mathrm{c}}$ & $0.008 \pm 0.02^{\mathrm{c}}$ & $1.62 \pm 0.05^{\mathrm{a}}$ & $0.12 \pm 0.06^{\mathrm{a}}$ \\
\hline
\end{tabular}

Mean values with the same superscripts $(a, b, c)$ in the same column are not significantly $(P \leq 0.05)$ different by $D M R T(P \geq 0.05)$.

Table 2a. Isolation and identification of hydrocarbon utilizing fungi isolates from the soil test samples.

\begin{tabular}{|c|c|c|c|}
\hline $\begin{array}{l}\text { Plot/soil } \\
\text { Sample }\end{array}$ & Fungi & Cultural characteristics & Cell morphology/microscopy \\
\hline \multirow{5}{*}{ I } & Aspergillus flavus & $\begin{array}{l}\text { Yellow-green velvet colony with white } \\
\text { border and yellow reverse }\end{array}$ & Septate hyphae with rough long conidiophores \\
\hline & Microsporium canis & $\begin{array}{l}\text { Whitish hairy fluffy colony with yellow } \\
\text { reverse }\end{array}$ & Septate hyphae with large conidia \\
\hline & Aspergillus terreus & $\begin{array}{l}\text { Brown velvet and powdery colony with } \\
\text { yellow reverse }\end{array}$ & Septate hyphae with short smooth conidiophores \\
\hline & $\begin{array}{l}\text { Penicillium sp. } \\
\text { Fusarium sp. }\end{array}$ & $\begin{array}{l}\text { Bluish-green with a white border } \\
\text { White cottony-like dusty colony }\end{array}$ & $\begin{array}{l}\text { Septate hyphae with brush-like conidiophores } \\
\text { Septate hyphae with branched conidiophores }\end{array}$ \\
\hline & Acremonium sp. & $\begin{array}{l}\text { White powdery cottony-like colony with } \\
\text { colourless reverse }\end{array}$ & Septate unbranched hyphae with oblong conidia \\
\hline \multirow{6}{*}{ II } & Malbranchea sp. & $\begin{array}{l}\text { White granular powdery colony with white } \\
\text { reverse }\end{array}$ & Septate hyphae without conidiophores \\
\hline & $\begin{array}{l}\text { Phaeoacremonium } \\
\text { parasiticum }\end{array}$ & $\begin{array}{l}\text { Cream and grayish velvet with brown } \\
\text { reverse }\end{array}$ & $\begin{array}{l}\text { Rough non-septate hyphae unbranched } \\
\text { conidiophores }\end{array}$ \\
\hline & Aspergillus terreus & $\begin{array}{l}\text { Brown velvet and powdery colony with } \\
\text { yellow reverse }\end{array}$ & Septate hyphae with short smooth conidiophores \\
\hline & $\begin{array}{l}\text { Trichophyton } \\
\text { terrestre }\end{array}$ & $\begin{array}{l}\text { White and yellow strain velvet with } \\
\text { colourlesss reverse }\end{array}$ & Septate hyphae with short stalks \\
\hline & Gliocladium sp. & $\begin{array}{l}\text { Dark-green fluffy colony that spread over } \\
\text { the plate with white reverse }\end{array}$ & $\begin{array}{l}\text { Septate hyphae with brush-like conidiophores } \\
\text { and clump conidia }\end{array}$ \\
\hline & $\begin{array}{l}\text { Aspergillus } \\
\text { nidulans }\end{array}$ & $\begin{array}{l}\text { Velvet army green colony with white border } \\
\text { and brown reverse }\end{array}$ & Septate hyphae with short smooth condiophores \\
\hline \multirow{5}{*}{ III } & Malbranchea sp. & $\begin{array}{l}\text { White granular powdery colony with white } \\
\text { reverse }\end{array}$ & Septate hyphae without conidiophores \\
\hline & $\begin{array}{l}\text { Trichophyton } \\
\text { tonsurans }\end{array}$ & $\begin{array}{l}\text { White and yellow strain velvet with yellow } \\
\text { reverse }\end{array}$ & Septate hyphae with short conidiophores \\
\hline & $\begin{array}{l}\text { Aspergillus } \\
\text { nidulans }\end{array}$ & $\begin{array}{l}\text { Velvet army green colony with white border } \\
\text { and brown reverse }\end{array}$ & Septate hyphae with short smooth condiophores \\
\hline & Fusarium sp. & White cottony-like dusty colony & Septate hyphae with branched conidiophores \\
\hline & Penicillium sp. & Bluish-green with a white border & Septate hyphae with brush-like conidiophores \\
\hline
\end{tabular}

considered low for agricultural activities. The present results agreed with earlier report; therefore the soil status of the Arboretum is poor.

However, the low total nitrogen and TOC may be attributed to the soil $\mathrm{pH}$ level which may have restricted microbial activities, reduced nitrification of organic matter significantly (Landon, 1991; Anderson and Domsch, 1980).

The soil analysis indicated that the soil was non-saline as showed by low values of electrical conductivity. Justen and Hodges (2007) reported that too much salt in the soil can interfere with root function and nutrient uptake which was not observed in the present research finding. They indicated that there was no risk of yield reduction for the tree grown in the arboretum. This is consistent with the report of Landon (1991).

\section{Microbes and their contribution}

The results in Table $2 \mathrm{a}$ showed in the hydrocarbon 
Table $\mathbf{2 b}$. Isolation and identification of hydrocarbon utilizing bacterial isolates from the soil test samples.

\begin{tabular}{|c|c|c|c|c|c|c|c|c|c|c|c|c|c|c|c|c|c|c|}
\hline \multirow{2}{*}{$\begin{array}{l}\text { Plot } \\
\text { Soil } \\
\text { Sample }\end{array}$} & \multirow{2}{*}{ 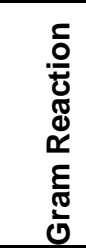 } & \multirow{2}{*}{$\begin{array}{r}\text { 흥 } \\
\frac{0}{0} \\
\overline{\bar{d}} \frac{0}{0} \\
\mathcal{U}\end{array}$} & \multirow{2}{*}{$\begin{array}{l}0 \\
0 \\
\frac{0}{0} \\
\frac{0}{x} \\
0 \\
\end{array}$} & \multirow{2}{*}{ 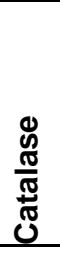 } & \multirow[b]{2}{*}{$\begin{array}{l}\frac{0}{\pi} \\
\stackrel{\frac{\pi}{2}}{0} \\
\end{array}$} & \multirow[b]{2}{*}{ 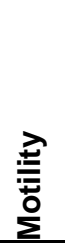 } & \multirow{2}{*}{$\begin{array}{l}\frac{n}{n} \\
\frac{c}{0} \\
\frac{0}{0} \\
\frac{0}{0} \\
\frac{0}{0}\end{array}$} & \multicolumn{4}{|c|}{ TSIA (Triple sugar ion agar) } & \multirow[b]{2}{*}{$\begin{array}{l}\text { 응 } \\
\text { 으 }\end{array}$} & \multirow{2}{*}{ 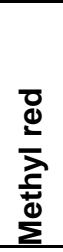 } & \multirow{2}{*}{ 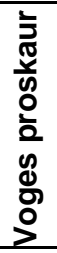 } & \multirow[b]{2}{*}{ 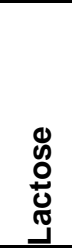 } & \multirow{2}{*}{ 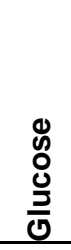 } & \multirow{2}{*}{ 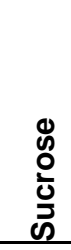 } & \multirow{2}{*}{ Bacterial isolatec } \\
\hline & & & & & & & & 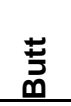 & 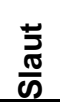 & $\begin{array}{l}\boldsymbol{N} \\
\text { I }\end{array}$ & 胥 & & & & & & & \\
\hline \multirow[t]{3}{*}{ I } & - & Rod & + & + & + & + & + & $A$ & $B$ & - & + & - & - & - & $A G$ & $A G$ & $A G$ & Alcaligenes sp. \\
\hline & + & cocci & + & + & + & - & + & B & B & - & - & - & - & - & $A G$ & $A G$ & $A G$ & Micrococcus sp. \\
\hline & - & Rod & - & + & - & - & + & B & B & - & - & + & - & - & $A G$ & AG & $A G$ & Acinetobacter sp. \\
\hline \multirow[t]{3}{*}{ II } & - & Rod & + & + & - & + & - & B & B & - & - & + & - & - & $A G$ & $A G$ & $A G$ & Pseudomonas sp. \\
\hline & - & Rod & - & + & - & + & + & $A$ & $B$ & - & - & + & - & - & $A G$ & AG & $A G$ & Acinetobacter sp. \\
\hline & - & Rod & + & - & + & - & - & B & B & - & - & - & - & - & $A G$ & $A G$ & - & Alcaligenes sp. \\
\hline \multirow[t]{2}{*}{ III } & + & Rod & + & + & + & + & + & $B$ & B & - & - & + & - & - & $A G$ & $A G$ & $A G$ & Bacillus sp. \\
\hline & - & Rod & - & - & + & + & + & A & B & - & - & + & + & - & $A G$ & $A G$ & $A G$ & Aeromonas sp. \\
\hline
\end{tabular}

$A=$ Acid, $B=$ Basic, $A G=A c i d / G a s$

utilizing fungi which was isolated and identified from the three subplot samples. Plot I, the fungi identified are; Aspergillus flavus, Microsporium canis, Aspergillus terreus, Penicillium sp. and Acremonium sp. while in Plot II, the fungal organisms found in the soil are Malbranchea sp., Phaeoacremonium parasiticum, Aspergillus terreus, Trichophyton terrestre, Gliocladium sp. and Aspergillus nidulans while Plot III the organisms found in the soil sample are Malbranchea sp., Trichophyton tonsurans, Aspergillus nidulans, Fusarium sp. and Penicillium $\mathrm{sp}$.

Generally there are twelve fungi found to be associated with the soil arboretum. However, in Table $2 \mathrm{~b}$, the number of bacterial found in the three subplot soil samples from each subplot. Plot I had the following bacterial present; Alcaligenes sp., Micrococous sp., and Acinetobacteria whereas in subplots II the bacterial organisms isolated and identified are Pseudomonas sp., Acinetebacter sp. and Allcaligenes sp. In subplot III, Bacillus sp. and Aeromonas sp. were found available in the soil samples collected.

It was generally observed that six hydrocarbon utilizing bacterial were isolated and identified in the forest soil Arboretum of Rivers state University, Port Harcourt. The result of total heterotrophic bacterial count (THBC), total fungi count (TFC), Hydrocarbon utilizing bacterial and hydrocarbon utilizing fungi count are presented in Table 3. The results indicated that hydrocarbon utilizing bacterial $\left(283 \times 2.8 \times 10^{4}\right)$ was most prevalent in the soil more than fungi hydrocarbon utilizer. Similarly, results obtained in the total heterotrophic bacterial count $\left(28 \times 2.8 \times 10^{6}\right)$ were more than total fungi count $\left(26 \times 2.6 \times 10^{6}\right)$.

Soil quality is the capacity of soil to maintain some key ecological functions, such as decomposing formation of soil organic matter
(Doran et al., 1996). The basic functions of soil microorganisms are the decomposition and transformation of organic materials which are mostly derived from above and below-ground plant residues. Thus soil microbial communities play a critical role in ecosystem processes such as carbon cycling and nutrient turnover (Ademir et al., 2009).

Similarly, Brendecke et al. (1993) reported that soil microbial activity as an indicator of soil fertility as a long term effects of municipal sewage sludge on an arid soil. Many microbes are involved in the process of biological nitrogen fixation and the enrichment of microbes in the alternative source for nitrogen (Postgate, 1998). The highest grain yield is obtained in soybean when inoculated with Bradhyrizobium in combination with NPK fertilizer.

Bacteria, fungi and Actnomycetes are known plant growth and yield either directly or indirectly (Hariprasad et al., 2009). In the present study, the 
Table 3. Isolation and identification of total heterotrophic bacterial and fungi on the sampled soil.

\begin{tabular}{lcc}
\hline Micro-organism isolate & Mean count & Colony farming unit per gram (cfu)g) \\
\hline THBC & 28 & $2.8 \times 10^{6}$ \\
TFC & 26 & $2.6 \times 10^{6}$ \\
HUBC & 28 & $2.8 \times 10^{4}$ \\
HUBC & 46 & $4.6 \times 10^{4}$ \\
\hline
\end{tabular}

Total heterotrophic bacterial count (THBC), total fungi count (TFC), hydrocarbon utilizing bacterial count (HUBC), and hydrocarbon utilizing fungi count (HUFC).

microbes such as bacteria fungi increased in their population when soil microbial activities, populations and communities are governed by environmental variables and organic system (Araujo et al., 2008; Melero et al., 2005).

\section{Conclusion and recommendations}

The knowledge of forest soil quality and microbial population of the Rivers State University arboretum is not documented. The present study has provided the basic information on some physicochemical properties, fungal and bacterial microbial population of the soil, since microorganisms are vital in nutrient cycling.

The present study has provided biodiversity baseline information on the soil quality on microbial population of the University arboretum. Forestry practices need to be prioritized as to increase the biological and economic yield per unit area of the forest while ensuring sustainability of the forest resources and there is a huge need to develop strategies for a sustainable protection of University arboretum soils for future generations.

\section{REFERENCES}

Abbey SD, 1995. Foundation in Medical Mycology. Bidsol and Company. Lagos. Pp. 35

Ademir SFA, Luiz FCL, Valdinar BS, Romero FVC, 2009. Soil microbial activity in conventional and organic agricultural systems. Sustainability, 1: 268-276.

Alexopoulos CJ, Mims CW, Blackwell M, 1962. Introductory Mycology, HC Jon Wiley And Sons Texa.

Anderson JPE, Domsch KH, 1980. Quantities of plant nutrients in the microbial biomass of selected soils. Soil Sci, 130(4): 211-216.

Araujo ASF, Santos VB, Monterios RTR, 2008. Responses of soil microbial biomas and activity for practices of organic and conventional farming system in Piaui state. Brazil European J Soil Biol, 44: 225-230.

Barnett HL, Hunter BB, 1972. Illustrated genera of imperfect fungi. $3^{\text {rd }}$ edition, Burgess Publishing Co., 273 pp.

Beare MH, Hendrix PF, Coleman DC, 1994. Water-stable aggregates and organic matter fractions in conventional and no-tillage soils. Soil Sci Soc Am J, 58: 777-786.

Brady NC, Weil RR, 2007. The Nature and Properties of Soils. $14^{\text {th }}$ ed. Pearson Education, Inc. 965.

Bremner JM, Mulvaney CS, 1982. Total Nitrogen. In: Methods of Soil Analysis, part 22nd Ed. (eds. A. L. Page, A. H. Miller and D. R. Keeney). ASA. SSSA Monograph No. 9, Madison, Wisconsin. 595624.
Brendecke JA, Lexson RD, Pepper IL, 1993. Soil microbial activity as an indicator of soil fertility: Long term effects of municipal sewage sludge on an arid soil. Soil Biol Biochem, 25: 751-758.

Buchanan RE, Gibbons NE, 1994. Bergey's Manual of Determinative Bacteriology, 9th Edition. The Wasiams and Wilkins Company, Baltimore, 39-596.

Buondonno A, Rishad A, Coppala E, 1993. Company tests for soils II: The hydrogen peroxide/sulfuric acid treatment as an alternative to the $\mathrm{Cu} / \mathrm{Se}$ catalyzed digestion process of routing determination of sod $\mathrm{N}$ Kjeldahl. Commun. Soils Sci Plant Anal, 26: 1607-1619.

Chukunda FA, Offor US, 2015. Studies of seed-borne pathogens of African breadfruits (Treculia africana Decne). Int J Agric Earth Sci, 1(8): 90-96.

Chukunda FA, Ukoima HN, Krukru BM, 2019. Assessment of Fungi and Bacteria Species in the Moringa oleifera Lam. and Annona muricata L. Rhizosphere of Arboretum, Rivers State University. J Agr Sci Soil Sci, 7 (10): 136-144

Cowan ST, 1974. Manual for Identification of Medical Bacteria. Cambridge University Press, Cambridge, 17-174.

Domsch KH, Gams W, Anderson TH, 1980. Compendium of fungi. $2^{\text {nd }}$ edition. England level on the establishment and growth of Moringa oleifera. Int J Agric Forest, 3(6): 226-230.

Doran JW, Sarrantonio M, Liebig MA, 1996. Soil health and sustainability. In Advances in Agronomy. Academic Press: San Diego, CA, USA, 56: 25-37.

Enger ED, Smith BF, 2008. Environmental Science: A Study of Interrelationships. 11th International Edition.

Gachene CKK, Kimaru C, 2003. Soil fertility and Land productivity: A guide for extension workers in the Eastern Africa Region. RELMA Technical handout Series 30. Nairobi, Kenya: Regional Land Management Unit (RELMA), Swedish International Development Cooperation Agency (SIDA). 164.

Glover GH, Tie-Qiang L, Ress D, 2000. Image-based method for retrospective correction of physiological motion effects in FMRI: RETROICOR. Magnetic Resonance in Medicine, 44(1):162 - 167.

Hanes, D.L (1984). Determination of organic carbon in soils by an improved chromic acid digestion and spectrophotometric procedure. Cornmun. Soils Sci Plant Anal, 15: 1191-1213.

Hariprasad P, Navya HM, Chandra NS, Niranjann SRC, 2009. Advantage of using PSIRB over PSRB and IRB to improve plant health of tomato. Biological Control, 50: 307-316.

Harrigan WF, McCance ME, 1990. Laboratory Methods in Food and Dairy Microbiology. 8th Edition. Academic Press, London. 136-138.

Justen BW, Hodges SA, 2007. Pollinator shifts drive increasingly long nectar spurs in columbine flowers. Nature, 447(7145): 706-709.

Landon JR, 1991. Booker Tropical Soil Manual. A handbook for soil survey and agricultural land evaluation in the tropics and subtropics. Longman Scientific and Technical Publishers, Essex. 474.

Lindo Z, Visser S, 2003. Microbial biomass, nitrogen and phosphorus mineralization and mesofauna in boreal conifev and deciduous forest floras following partial and clear cut harvesting. Can J Forest Res, 13: 1610-1620.

Mclean EO, 1982. Soil pH and lime Requirement. In page, A. L Ed, Methods of Soil Analysis Part 2 Chemical.

Melero S, Porras JCR, Herencia JF, Madejon F, 2005. Chemical and biochemical properties in a silly loan soil under conventional organic management. Soil Tillage Res, 90: 162-170. 
Monger HC, Bestelmeyer BT, 2006. The soil-geomorphic template and biotic change in deserts. J Arid Environ, 65: 207-218.

Murphy J, Riley JP, 1962. A modified single solution method for determination of phosphate in natural waters. Anal Chimica Acta, 27: 31-36.

Nandi A, Luffman I, 2012. Erosion related changes to physicochemical properties of Ultisols distributed on calcareous sedimentary rocks. J Sustain Dev, 5(8): 52-68.

Nelson DW, Sommers LE, 1982. Total carbon, organic carbon and organic matter. In: Methods of Soil Analysis, Part 2, 2nd Edn. (eds. Page AL, Miller RH, Keeney DR.). ASA, SSSA Monograph No. 9, Madison, Wisconsin. 39-579.

Obire O, Wemedo SA, 1996. The effect of oilfield wastewater on the microbial populations of a soil in Nigeria. Niger Delta Biologia, 1:7785.

Ofunne JI, 1999. Bacteriological examination of clinical specimens. Achugo Publications, Ama J.K. Recreation Park, Owerri, Nigeria.

Postgate JR, 1998. Nitrogen Fixation. 3rd edn. Cambridge University Press, Cambridge, UK.

Shawna WL, Anna JK, Paula S, Tom C, 2010. Independent Study 490A: Canine Behavior Evaluations: Can it Predict Canine Aggression and Therefore Improve Subsequent Adoption Rates?, Animal Industry Report: AS 656, ASL R2513.

Steel RGD, Torrie JA, 1980. Principles and Procedures of Statistic: A Biometrical Approach.

Tariah NW, Zuofa K, Doughlas DC, 1991. Diagnostic survey in Rivers State: A cropping system case study of Nchia in Eleme Districts. Nig J Crop Sci Forestry, 1(1): 13-18.

Waser H, Yussefi M, 2004. The World of Organic Agriculture: Statistics and Emerging Trends. International Federation of Organic Agriculture Movements: Bonn, Germany, 167.

Watanabe FS, Olsen SR, 1965. Test of an ascorbic acid method for determining phosphorus in water and $\mathrm{NaHCO}_{3}$ extracts from soil. Soil Sci Soc Am Proc, 29(6): 677-678.
Citation: Chukunda FA, Baraka RE, Alika V C, 2020. Soil quality and microbial population of the Rivers State University Arboretum, Port Harcourt, Nigeria. M icrobiol Res Int, 8(1): 15-21. 